University of Nebraska - Lincoln

DigitalCommons@University of Nebraska - Lincoln

2000

Temporal Flexibility of Reproduction in Temperate-Breeding Dabbling Ducks

Gary Krapu

USGS Northern Prairie Wildlife Research Center, gkrapu@usgs.gov

Follow this and additional works at: https://digitalcommons.unl.edu/usgsnpwrc

Part of the Other International and Area Studies Commons

Krapu, Gary, "Temporal Flexibility of Reproduction in Temperate-Breeding Dabbling Ducks" (2000). USGS Northern Prairie Wildlife Research Center. 44.

https://digitalcommons.unl.edu/usgsnpwrc/44

This Article is brought to you for free and open access by the US Geological Survey at DigitalCommons@University of Nebraska - Lincoln. It has been accepted for inclusion in USGS Northern Prairie Wildlife Research Center by an authorized administrator of DigitalCommons@University of Nebraska - Lincoln. 


\title{
TEMPORAL FLEXIBILITY OF REPRODUCTION IN TEMPERATE-BREEDING DABBLING DUCKS
}

\author{
GARY L. KRAPU ${ }^{1}$ \\ United States Geological Survey, Northern Prairie Wildlife Research Center, Jamestown, North Dakota 58401, USA
}

\begin{abstract}
I compared nesting intervals during three consecutive years in five species of temperate-nesting dabbling ducks (Mallard [Anas platyrhynchos], Northern Pintail [Anas acuta], Northern Shoveler [Anas clypeata], Blue-winged Teal [Anas discors], Gadwall [Anas strepera]) and assessed whether differences existed in timing of refractoriness. Most nesting by females of all five species ended by the summer solstice. Nesting ended earliest for Northern Shovelers and Northern Pintails and latest for Gadwalls. Some Mallards, Blue-winged Teal, and Gadwalls continued to nest into mid- and late summer, whereas Northern Shovelers and Northern Pintails did not. Mallards, Blue-winged Teal, and Gadwalls accounted for 99\% (81 of 82) of flightless broods resulting from nests initiated during mid- or late summer in North Dakota and $98 \%$ (58 of 59) of flightless juveniles shot on or after 1 October by a random sample of duck hunters from across the United States. Early cessation of breeding by Northern Shovelers may have evolved in response to the species' limited flexibility in diet. Photorefractory mechanisms that limit most breeding to spring presumably evolved in response to severe constraints on reproductive success when nesting continued through summer (e.g. mortality of late-hatched young and molting females due to low temperatures). Interspecific differences in photosensitivity may account for variation in timing of cessation of nesting in late spring, but controlled experiments are needed to assess the possible role of non-photic influences. My results suggest that the refractory mechanisms controlling length of the breeding season in temperate-nesting dabbling ducks are more varied and complex than previously thought, with non-photic influences (e.g. water conditions, food availability, food quality) having a larger role than indicated by earlier research. Received 25 January 1999, accepted 23 November 1999.
\end{abstract}

REPRODUCTIVE FITNESS of individuals is enhanced by timing reproductive efforts to coincide with environmental conditions that maximize survival of young and parents (Farner et al. 1983). Termination of breeding cycles in temperate-nesting waterfowl in the Northern Hemisphere is accomplished through photorefractoriness, a process by which levels of plasma gonadotropins decline under day lengths that otherwise induce or maintain high levels (Hahn et al. 1997). In the waterfowl genus Anas, environmental conditions under which species evolved, and thus length of the period when breeding could occur successfully, presumably varied widely among species. As a result, refractory mechanisms may reflect interspecific variation in the duration of successful reproduction. However, quantitative evidence of variation in timing of refractoriness among temperate-nesting Anas is lacking.

Photorefractoriness does not occur under long day lengths in late spring among species

\footnotetext{
${ }^{1}$ E-mail: gary_krapu@usgs.gov
}

of dabbling ducks that breed in temperate regions of the Southern Hemisphere (Murton and Kear 1976). Species confined mostly to the tropics or otherwise distributed in the Southern Hemisphere have breeding seasons that are long and symmetrically positioned in relation to the summer solstice ("Type $\mathrm{A}^{\prime}$ species of Murton and Kear [1976]). Type A species potentially can continue to breed until day length shortens to lengths that no longer are stimulatory. Conversely, species that nest in temperate regions of the Northern Hemisphere have distinct short breeding seasons that end at long day lengths around the summer solstice ("Type B" species). Among the Type B species, long day length in late spring and early summer generally is considered to be the decisive factor that controls the end of breeding for the season. Type B species have photorefractory mechanisms that cause breeding to cease spontaneously when day lengths are still stimulatory (Murton and Kear 1976). Among Mallards (Anas platyrhynchos), the most studied species of the Type B group, laying dates, testicular 
mass changes, and histological investigations of the testes suggest that germ cell production is restricted to the period from March through June in the wild and in captivity (Hohn 1947; Johnson 1961, 1966; Donham 1979). Verification of absolute photorefractoriness in Mallards by late June under long day lengths has been demonstrated experimentally (Lofts and Coombs 1965, Haase 1983, Haase et al. 1985).

Despite much evidence that temperate-nesting ducks are absolutely photorefractory under long day lengths in late spring and early summer (clearly fitting within the Type B category), I observed major breeding activity by dabbling ducks, including Mallards, throughout the summer of 1962 in southeastern North Dakota (Bluhm 1992:343). Summer breeding in 1962 occurred in one of the wettest recorded summers for southeastern North Dakota (NOAA 1892-1996). Rainfall from May through July totaled 13.5, 11.4, and $22.9 \mathrm{~cm}$ at Fullerton (where observations of summer breeding occurred), and July 1962 was the wettest on record. Over the next three decades, no comparable patterns of precipitation occurred during late spring and summer in southeastern North Dakota, nor were similar patterns of flooding observed. From 1963 to 1992, neither I nor colleagues at the Northern Prairie Wildlife Research Center saw evidence of large-scale mid- and late summer nesting by dabbling ducks in eastern North Dakota. The lack of conspicuous summer breeding by dabbling ducks in the years following 1962 led me to hypothesize that the extended nesting season in 1962 was due to stimulation resulting from the wet summer.

In 1993, record amounts of rain fell from late spring through summer across a large area of the midwestern United States (USACE 1994), producing extensive flooding of wetland habitats across the region. With water conditions similar to 1962 in eastern North Dakota, I initiated studies to assess whether length of breeding varied among temperate-nesting dabbling ducks, and if so, to evaluate possible causes for the variation. Specifically, I focused on five common species (Mallard, Northern Pintail [Anas acuta], Northern Shoveler [Anas clypeata], Blue-winged Teal [Anas discors], Gadwall [Anas strepera]) that breed in the Prairie Pothole Region (PPR), the principal breeding area of dabbling ducks in North America (Bellrose 1979), to determine whether differences existed among species in timing of cessation of breeding and to use this information to infer whether differences occur in timing of photorefractoriness and / or in responsiveness to cues delaying its onset.

\section{Study Areas And Methods}

Data to assess variation in nesting intervals among the five species in late spring were collected on a series of plots distributed across the Prairie Pothole Region (PPR) of North Dakota and north-central South Dakota (the spring nest survey area [SNSA]). An assessment of nesting during summer by each of the five species was obtained from fall brood surveys on a 3,833- $\mathrm{km}^{2}$ study site in Stutsman and Barnes counties in eastern North Dakota (the fall brood survey area [FBSA]) and across the United States based on frequency and distribution of flightless juveniles of each species in the bag of duck hunters.

Spring and early summer nesting intervals and nesting success.-I used spring and early summer nesting records to test for interspecific differences among the five species in dates of nest initiation and to compare rates of nesting success. The sample of nests was obtained by searching a stratified random sample of fields enrolled in the Conservation Reserve Program (CRP) in the PPR of North Dakota and north-central South Dakota. Fields searched were distributed across $12810-\mathrm{km}^{2}$ sites, each of which contained at least 16.2 ha of CRP cover. The sites form a subset of those used in studies described by Reynolds et al. (1994). Data on nesting duration and nesting success were obtained through a minimum of three systematic nest searches of each plot between early May and early July 1993 to 1995 following standard methods (Klett et al. 1986). Laying or incubating females were identified to species when flushed, the number of eggs in each nest was determined, and the stage of egg development was established by candling (Weller 1956). The date of initiation of egg laying was estimated by backdating, taking into account stage of incubation and clutch size, and assuming that one egg was laid daily until the clutch was complete. Nests were revisited every 7 to 10 days until at least one egg hatched, the nest was abandoned, or the nest was totally destroyed. On each revisit to a nest, species identity and date were recorded, number of eggs was identified, and completed clutch size was recorded, if known. Nest fate was recorded on the last visit. A nest was deemed successful if at least one egg hatched, indicated by the presence of shell membranes (Klett et al. 1986) or ducklings in the nest bowl. Nesting success was estimated using the modified Mayfield technique (Johnson 1979).

Frequency and distribution of summer nesting.-September brood surveys were conducted to evaluate which species continued to nest into mid- and late 
summer and to evaluate temporal chronology of mid- and late summer nesting. September brood surveys were timed to allow nests initiated before about 20 August to have hatched prior to the surveys. To assess relative frequency and duration of nesting by the five species in mid- and late summer, I measured numbers of broods of each species seen by age class within transects located on the FBSA which was centrally located within the SNSA. Initially, the FBSA was divided into 30 plots of equal size $(13.7 \times 9.4$ $\mathrm{km})$, but one was dropped when inspection revealed a large reservoir that encompassed most of the plot. Within the remaining 29 plots, $19 \mathrm{~km} \times 0.4 \mathrm{~km}$ transects $(0.2 \mathrm{~km}$ on each side of roads) were established randomly within the existing road system. We had enough people to survey 18 transects in random order. Transect surveys were conducted on 20 to 21 September 1993, 14 to 15 September 1994, and 13 to 14 September 1995. Coverage of transects was limited to wetlands visible from roads. Broods were identified to species and brood ages were estimated from plumage development (Gollop and Marshall 1954). Brood visibility during fall 1993 to 1995 was excellent because water levels were high and vegetation was defoliated by frost and senescence. In 1993, the initial survey was followed by a survey of broods during 22 to 30 September on 6 of the 29 plots. Similar data were gathered on plots and transects, and coverage of plots also was limited to wetlands visible from roads. For each brood, I estimated nest-initiation date by backdating as follows: I summed the age of the brood in days (age-class midpoint; Gollop and Marshall 1954), the average incubation period of the species (Bellrose 1980), and the number of days required for laying of a clutch of average size (Bellrose 1980) assuming a laying rate of one egg daily until the clutch was completed, and then subtracted this sum from the Julian date of the survey.

Random surveys of the bag of duck hunters provided information to assess the relative frequency and distribution of mid- and late-summer breeding across the United States. Frequency of occurrence of flightless juveniles shot on or after 1 October provided a measure of which species nested in mid- and late summer and the distribution of summer breeding. Data were obtained from the annual fall duck harvest survey from states in the Central Flyway (North Dakota, South Dakota, Nebraska, Oklahoma, Texas, and parts of Montana, New Mexico, Colorado, and Wyoming) during 1993 and throughout the United States in 1994 to 1995. Selected hunters were asked to remove a wing from each duck harvested during the fall and submit wings to the Migratory Bird Management Office. Wings of flightless juveniles were separated from the rest of the wing sample and identified to species. Only young with primaries not having developed beyond the "blood quill" stage were included so that the sample was limited to young that were locally reared from nests initiated in mid- to late summer.

Statistical analyses.-I used randomized block analysis of variance (ANOVA), with year as a blocking factor and species as a classification factor, to compare percentiles of nest-initiation dates. To maintain an error rate of $\alpha=0.05$ for each percentile, I employed Bonferroni's correction, rejecting null hypothesis of no differences among species when I found evidence of differences at $P \leq 0.01$. When ANOVA revealed evidence of differences among species, I used Fisher's protected LSD test to conduct multiple comparisons to determine which species differed. I used S-PLUS 4.0 (Mathsoft 1997) to perform statistical analyses.

\section{RESUlts}

Interspecific differences in nesting intervals during spring.-Mallards and Northern Pintails (hereafter pintails) nested first and Gadwalls nested last (Fig. 1). Nesting was completed first by Northern Shovelers (hereafter shovelers) and pintails followed by Mallards and Bluewinged Teal and then Gadwalls (Table 1). Shovelers initiated nesting third (Fig. 1) but were the first to complete $50 \%$ of nest initiations (Table 1). Pintails began nesting about two weeks earlier than shovelers (Fig. 1) and terminated nesting on a schedule slightly behind shovelers (Table 1). Interspecific differences in length of nesting was not explained by nesting success rates (Table 2). For all five species, most nest initiations ended by about 21 June (Fig. 1).

Interspecific differences in breeding frequency and distribution during summer.-Of broods seen on transects and plots during September and estimated to have hatched from nests initiated after 10 July, 81 of 82 (99\%) were Mallards, Blue-winged Teal, and Gadwalls (Table 3, Fig. 2). Mallards, Blue-winged Teal, and Gadwalls continued to nest an estimated 58,56, and 47 days, respectively, beyond the summer solstice (Fig. 2). The last nest initiations for Bluewinged Teal, Mallards, and Gadwalls, based on fall brood surveys, were estimated to be 18,16 , and 7 August, respectively. The latest estimated nest-initiation date for a dabbling duck species, based on an opportunistic sighting, was 3 September for Mallards (based on a class 1 brood sighted on the FBSA during late October 1993). The last Mallard, Blue-winged Teal, and Gadwall nests known to have been initiated in 1993 were near the low end of day lengths that stimulated breeding in spring (Fig. 2). Blue- 


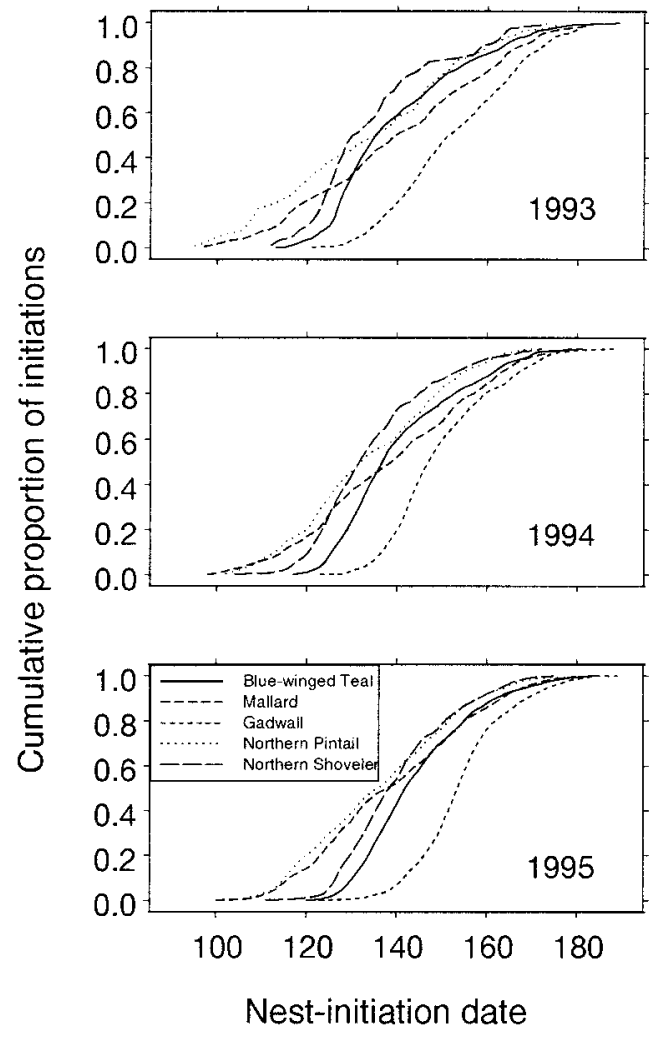

FIG. 1. Cumulative proportion of nest initiations completed by Julian date among Mallards, Bluewinged Teal, Gadwalls, Northern Pintails, and Northern Shovelers during spring and early summer, 1993 to 1995, in the Prairie Pothole Region of North Dakota and north-central South Dakota.

winged Teal accounted for 70 and $83 \%$ of dabbling duck broods observed from nests initiated after 10 July 1993 and 1994, respectively. Mid- and late summer nesting was most frequent during 1993 (Table 3). The number of broods seen on transects from nests initiated after 10 July declined sharply from 1993 to 1994 and 1995 (Table 3), as did sightings of dabbling duck broods across the FBSA.

Ninety-eight percent (58 of 59) of flightless young of the five species shot on or after 1 October 1993 to 1995 by duck hunters across the United States were Mallards, Blue-winged Teal, and Gadwalls. Only one flightless juvenile shoveler, and no flightless juvenile pintails, were in the sample of wings. Flightless young Mallards, Blue-winged Teal, and Gadwalls reported by hunters were from 7,5 , and 4 states in the western and central United States (Table 4). The number of shot flightless juveniles that came from nests initiated in mid- or late summer declined from 35 in 1993 to 12 each in 1994 and 1995.

\section{DiscUSSION}

Causes of interspecific variation in when dabbling ducks terminate breeding and presumed differences in timing of refractoriness are unknown. However, interspecific differences in timing of cessation of breeding presumably result, in part, because environmental constraints that prevent reproductive success vary among species. Shovelers and pintails are the first to terminate breeding in spring (Table 1), and they seldom nest in summer (Fig. 2), suggesting that environmental conditions that prevent reproductive success are encountered earlier in the season than among Blue-winged Teal, Mallards, and Gadwalls. For shovelers, spatulate mandibles with finely spaced lamellae (Nudds and Bowlby 1984) limit foraging primarily to small crustaceans and snails (Swanson et al. 1979). Cladocera, the principal food of laying females and young shovelers, are among the most abundant invertebrates in

TABLE 1. Mean range of Julian dates when 50, 75, 90, 95, and 99\% of nests initiated by Northern Shovelers, Northern Pintails, Blue-winged Teal, Mallards, and Gadwalls were completed during 1993 to 1995 in North Dakota and north-central South Dakota.

\begin{tabular}{lrlcccc}
\hline \hline & & \multicolumn{4}{c}{$\%$ Nest initiations completed by Julian date } \\
\cline { 3 - 7 } \multicolumn{1}{c}{ Species } & $n$ & \multicolumn{1}{c}{50} & 75 & 90 & 95 & 99 \\
\hline Northern Shoveler & 928 & $130-138^{\mathrm{A}}$ & $141-149^{\mathrm{A}}$ & $154-159^{\mathrm{A}}$ & $159-164^{\mathrm{A}}$ & $169-173^{\mathrm{A}}$ \\
Northern Pintail & 902 & $132-136^{\mathrm{A}, \mathrm{B}, \mathrm{C}}$ & $146-149^{\mathrm{A}, \mathrm{B}}$ & $155-160^{\mathrm{A}}$ & $161-167^{\mathrm{A}}$ & $167-176^{\mathrm{A}}$ \\
Blue-winged Teal & 2,783 & $135-142^{\mathrm{B}, \mathrm{C}}$ & $149-152^{\mathrm{B}, \mathrm{C}}$ & $162-164^{\mathrm{B}}$ & $167-170^{\mathrm{B}}$ & $173-178^{\mathrm{B}}$ \\
Mallard & 1,167 & $138-139^{\mathrm{B}}$ & $153-157^{\mathrm{C}}$ & $163-167^{\mathrm{B}}$ & $168-172^{\mathrm{B}}$ & $175-183^{\mathrm{B}}$ \\
Gadwall & 2,314 & $147-154^{\mathrm{D}}$ & $157-164^{\mathrm{D}}$ & $167-172^{\mathrm{C}}$ & $172-177^{\mathrm{C}}$ & $179-181^{\mathrm{C}}$ \\
\hline
\end{tabular}

a Within columns, entries with the same superscript are not significantly different $(P>0.05)$. 
TABLE 2. Mayfield nesting success (95\% confidence limits in parentheses) for Northern Shovelers, Northern Pintails, Blue-winged Teal, Mallards, and Gadwalls during 1993 to 1995 in North Dakota and north-central South Dakota.

\begin{tabular}{lccc}
\hline \hline \multicolumn{1}{c}{ Species $^{\mathrm{a}}$} & 1993 & 1994 & 1995 \\
\hline Northern Shoveler & $0.34(0.26-0.43)$ & $0.53(0.48-0.59)$ & $0.39(0.34-0.44)$ \\
Northern Pintail & $0.33(0.24-0.45)$ & $0.41(0.35-0.48)$ & $0.29(0.25-0.34)$ \\
Blue-winged Teal & $0.32(0.28-0.37)$ & $0.42(0.38-0.45)$ & $0.36(0.33-0.39)$ \\
Mallard & $0.26(0.20-0.33)$ & $0.37(0.33-0.42)$ & $0.32(0.28-0.35)$ \\
Gadwall & $0.39(0.34-0.44)$ & $0.45(0.41-0.49)$ & $0.32(0.29-0.35)$ \\
\hline
\end{tabular}

a Sample sizes of nests from 1993 to 1995, respectively, are: Northern Shoveler = 134, 367, 410; Northern Pintail = 96, 293, 500; Blue-winged Teal $=456,884,1,306 ;$ Mallard $=198,537,859 ;$ Gadwall $=352,785,1,098$.

spring (Bataille and Baldassarre 1993) but are much less abundant by August (Hall 1964, DuBowy 1988). As a result, shoveler ducklings may have become food limited earlier in the season than other dabbling ducks, leading to the evolution of a refractory mechanism that resulted in an early termination of breeding. Breeding female shovelers forage in several types of wetlands including permanent ponds (Poston 1969), suggesting that the early termi- nation of breeding was not linked to seasonal changes in pond abundance. The possibility exists that seasonal declines in food resources prevent female shovelers from nesting in summer, so experiments are needed to establish whether length of breeding can be extended beyond intervals occurring in the wild when appropriate food is provided ad libitum.

Pintails breed early, seeking out temporarily flooded ponds (Smith 1970) that are the first to

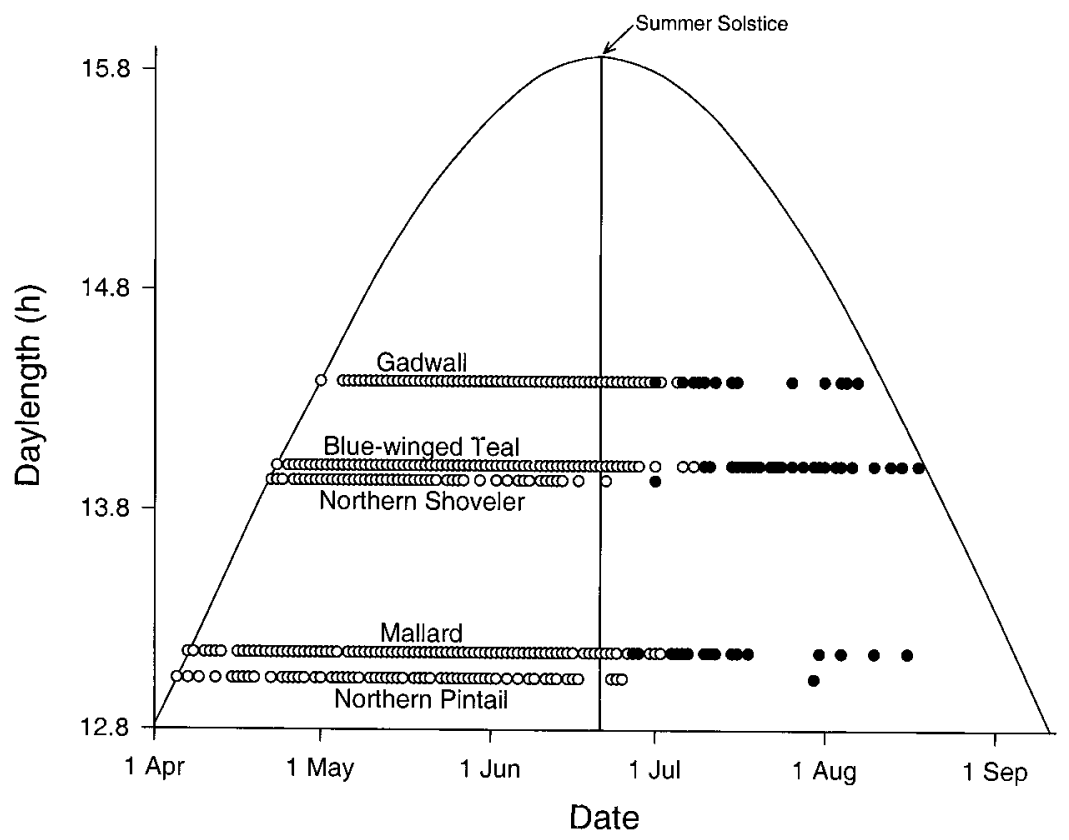

FIG. 2. Breeding intervals for Mallards, Northern Pintails, Northern Shovelers, Blue-winged Teal, and Gadwalls by day length during spring and summer of 1993 in eastern North Dakota. White circles denote one or more nest initiations based on nest surveys conducted from early May through early July 1993 in North Dakota and north-central South Dakota. Black circles denote dates of one or more nest initiations based on broods sighted on transects and plots surveyed during 20 to 30 September 1993 in Barnes and Stutsman counties, eastern North Dakota. Summer nest-initiation dates were estimated by backdating broods of known age class. Some records denoted by white and black circles are hidden from view because of multiple nest initiations on the same date. 
TABlE 3. Species composition (\%) of Mallard, Gadwall, Blue-winged Teal, Northern Shoveler, and Northern Pintail broods that hatched from nests estimated to have been initiated during mid- and late summer (after 10 July). Surveys were conducted during September 1993 to 1995 on 18 transects randomly distributed across Barnes and Stutsman counties, eastern North Dakota. The number of broods seen during surveys is in parentheses.

\begin{tabular}{|c|c|c|c|c|}
\hline & \multicolumn{2}{|c|}{1993} & \multirow{2}{*}{$\frac{1994}{\text { Transects }}$} & \multirow{2}{*}{$\frac{1995}{\text { Transects }}$} \\
\hline & Transects & Plots $^{\mathrm{a}}$ & & \\
\hline Mallard & $3.2(1)$ & $23.3(10)$ & $16.7(1)$ & $0.0(0)$ \\
\hline Gadwall & $19.4(6)$ & $9.3(4)$ & $0.0(0)$ & $50.0(1)$ \\
\hline Blue-winged Teal & $74.2(23)$ & $67.4(29)$ & $83.3(5)$ & $50.0(1)$ \\
\hline Northern Shoveler & $0.0(0)$ & $0.0(0)$ & $0.0(0)$ & $0.0(0)$ \\
\hline Northern Pintail & $3.2(1)$ & $0.0(0)$ & $0.0(0)$ & $0.0(0)$ \\
\hline Total & $100.0(31)$ & $100.0(43)$ & $100.0(6)$ & $100.0(2)$ \\
\hline
\end{tabular}

a Data from six plots surveyed one to nine days after the initial transect survey.

warm in spring and produce macroinvertebrates that are sought by females during egg production (Krapu 1974). Pintails also are highly mobile, have weak pair bonds (Derrickson 1978), fledge in as short a period as 42 days in the PPR (Bellrose 1980), and rely the most on endogenous lipids to produce their first clutch of eggs among species of dabbling ducks that have been studied (Esler and Grand 1994). These traits suggest that pintails evolved under environmental conditions that required breeding to begin and end early to achieve reproductive success. For pintails, like shovelers, the possibility exists that a seasonal decline in foods required by females for successful breeding, particularly after lipid reserves are exhausted by mid-May (Krapu 1974), accounts for the early termination of breeding. However, female pintails continue to nest after lipid reserves are depleted if wetland conditions are favorable, and during egg production females feed on a variety of animal and plant foods (Krapu 1974), including several that remain plentiful in wet late springs and summers.

Female Mallards, like pintails, start breeding early, rely on endogenous lipids for production of early clutches (Krapu 1981), and prefer temporary and seasonal ponds during egg production (Krapu et al. 1997). Mallard brood survival declines as the availability of seasonal basins with water decreases (Krapu et al. 2000), indicating that seasonal ponds are important to reproductive success. However, other traits of female Mallards, e.g. homing at relatively high rates to sites where they bred successfully the previous year (Lokemoen et al. 1990) and breeding in association with semipermanent ponds and lakes (Krapu et al. 1997), suggest that Mallards evolved under more stable environmental conditions than pintails, leading to the evolution of a refractory mechanism that allows breeding to continue later in spring.

TABLE 4. Species composition and geographic distribution of flightless juvenile dabbling ducks shot on or after 1 October by a random sample of hunters during 1993 to 1995 based on the annual duck harvest survey conducted by the U.S. Fish and Wildlife Service.

\begin{tabular}{|c|c|c|c|c|c|c|}
\hline State & $\begin{array}{l}\text { Blue-winged } \\
\text { Teal }\end{array}$ & Mallard & Gadwall & $\begin{array}{l}\text { Northern } \\
\text { Pintail }\end{array}$ & $\begin{array}{l}\text { Northern } \\
\text { Shoveler }\end{array}$ & Totals \\
\hline California & 1 & - & - & - & - & 1 \\
\hline Colorado & - & 1 & - & - & - & 1 \\
\hline Michigan & - & 1 & - & - & - & 1 \\
\hline Minnesota & 1 & 2 & - & - & - & 3 \\
\hline North Dakota & 5 & 15 & 9 & - & 1 & 30 \\
\hline Nebraska & 2 & 3 & - & - & - & 5 \\
\hline Nevada & - & - & 1 & - & - & 1 \\
\hline Oregon & - & - & 1 & - & - & 1 \\
\hline South Dakota & 4 & 6 & 3 & - & - & 13 \\
\hline Wisconsin & - & 3 & - & - & - & 3 \\
\hline Totals & 13 & 31 & 14 & 0 & 1 & 59 \\
\hline
\end{tabular}


Blue-winged Teal breed primarily in the PPR (Bellrose 1980), start nesting much later than Mallards (Fig. 1), but also prefer temporary and seasonal ponds (Drewien and Springer 1969). Teal breed successfully in association with temporary and seasonal ponds, despite a relatively late onset of breeding, because they are strong "pioneers." Teal shift their distribution annually, settling in landscapes where high runoff from snowmelt or spring rains results in an abundance of recently flooded ponds (Johnson and Grier 1988). This reproductive strategy enhances reproductive success in years when water is plentiful across part or all of the PPR. The high proportion of teal among broods from summer-initiated nests (Table 3) suggests that teal are particularly responsive to high amounts of rainfall in late spring and summer that cause temporarily flooded wetlands to increase during this period.

Gadwalls are the last of species to initiate nesting (Fig. 1) and continue to nest later in spring, on average, than the other four species (Table 1). Gadwalls commonly breed in association with brackish semipermanent and saline wetlands (Serie and Swanson 1976), suggesting that they evolved in an environment where a late onset of breeding was adaptive, leading to less reliance on temporary and seasonal ponds than pintails, Mallards, and Bluewinged Teal.

Although timing of onset of nesting varied widely among the five studied species, most nesting ended by about the summer solstice (Fig. 1, Table 1). Gadwalls, despite a late onset of breeding, still completed most nesting by early summer (Fig. 1). The fact that most females of all five species, including early and late breeders, terminated breeding by early summer suggests that mechanisms for the timing of refractoriness evolved under conditions where severe environmental constraints lowered reproductive success when nesting continued through summer. Ducklings produced from summer-initiated nests in 1993 experienced high mortality, lending support to the hypothesis that the annual decline in ambient temperature during late summer and fall was a major factor contributing to evolution of photorefractory mechanisms that limited most breeding to spring in temperate-nesting dabbling ducks. In 1993, an estimated 67, 66, and
$77 \%$, respectively, of Blue-winged Teal, Mallard, and Gadwall broods from summer-initiated nests were in age classes $1 \mathrm{a}$ to $2 \mathrm{c}$, and most of these young disappeared and presumably died after temperatures during the nights of 30 September and 1 October fell to $-2.2^{\circ} \mathrm{C}$ and $-3.3^{\circ} \mathrm{C}$, respectively, and shallow ponds froze (G. Krapu unpubl. data). Declining food resources may have contributed to the evolution of refractory mechanisms that led to an early cessation of breeding in some species (e.g. Northern Shovelers). However, class 2 brood sizes of Mallards, Blue-winged Teal, and Gadwalls when surveyed on transects and plots during 20 to 30 September 1993 were large, i.e. $7.3 \pm$ SE of $0.7(n=12), 6.8 \pm 0.4(n=32)$, and $7.9 \pm 0.6(n=7)$ ducklings, respectively (G. Krapu unpubl. data), indicating that duckling survival was high during summer and early fall and implying that food remained plentiful into fall after wet summers. Many females that raised late broods in 1993 attempted to molt their primaries during October 1993 and died before or during freeze-up. This pattern suggests that increased mortality of summer-nesting females also contributed to the evolution of refractory mechanisms that limit breeding mostly to spring.

Species-specific differences in timing of cessation of breeding (Fig. 1, Table 1) imply interspecific variation in photosensitivity. Speciesspecific differences in photosensitivity as day length increases in late spring may explain why reproduction consistently terminates earliest in pintails and shovelers, followed by Mallards and Blue-winged Teal and then Gadwalls. Alternatively, pintails and shovelers possibly evolved lower responsiveness to non-photic cues (e.g. rainfall, wetland habitat conditions) than Mallards, Blue-winged Teal, and Gadwalls, leading to observed interspecific differences in timing of termination of breeding. However, the latter hypothesis is not supported by information from the PPR of Canada, which indicates that the mean length of extension of the nesting interval for pintails and Mallards increased 0.12 and 0.10 days for each $1.0 \mathrm{~cm}$ increase in precipitation during May (Greenwood et al. 1995). Controlled experiments will be required to conclusively demonstrate whether interspecific variation in photosensitivity, differing sensitivities to non-photic cues, or other factors are responsible for interspecific 
differences in the timing of cessation of breeding.

Reproductive mechanisms in the five dabbling duck species studied are sensitive to wetland habitat conditions because of the influence of pond conditions on reproductive success. The proportion of unsuccessful female Mallards, pintails, Blue-winged Teal, and Gadwalls that continue to renest in the PPR as the breeding season advances varies with the number of May ponds (Greenwood et al. 1995), and seasonal ponds account for most of the variation in pond availability in May, June, and July (Krapu et al. 2000). Females of the five species studied rely principally on aquatic invertebrates for protein needs during egg production (Krapu and Reinecke 1992), and the abundance of May ponds influences standing crop and spatial distribution of aquatic invertebrates. Availability of high-quality food influences the number of clutches that can be produced (Eldridge and Krapu 1988).

When temporary and seasonal basins are dry during widespread drought conditions, many dabbling ducks either fail to nest (Smith 1971) or terminate nesting early (Krapu et al. 1983). Under drought conditions in prairie Canada in 1959, female Mallards gathered into flocks by late May, and examination of their reproductive tracts revealed atretic ova but no evidence of ovulated follicles (Dzubin and Gollop 1972), indicating a lack of nesting and an early onset of refractoriness. For female Mallards that attempt to breed under drought conditions, the risk of failure is high. Among Mallards breeding in North Dakota and west-central Minnesota, the risk of brood loss was estimated to be 11 times greater when less than $17 \%$ of seasonal wetland basins contained water compared with when more than 59\% were filled (Krapu et al. 2000). The influence of water conditions on brood survival results, in part, because Mallard ducklings rely on seasonal ponds for invertebrates that provide protein for growth and survival during the first several weeks posthatching (Cox et al. 1998). Because the availability of temporary and seasonal ponds in spring and summer varies widely among years (Krapu et al. 1997, USFWS 1998), reproductive success varies accordingly for species that are dependent on these pond types. The number of July ponds is highly correlated with the number of May ponds in the PPR (Pospahala et al.
1974), so the level of expected risk to broods is factored into the "decision" by females regarding when to terminate reproduction for the season.

Some Mallards, Blue-winged Teal, and Gadwalls did not become photorefractory under long day lengths and continued to nest until day lengths were no longer stimulatory (Fig. 2), apparently due in part to stimulation from non-photic cues. Summer nesting by Mallards, Blue-winged Teal, and Gadwalls apparently was highest in 1993 (Table 3) when high rainfall led to an abundance of newly flooded wetland habitat in late spring and summer. It probably is more than coincidental that the unusually large mid- and late summer breeding responses by dabbling ducks in 1962 and 1993 in North Dakota immediately followed major three-tofour-year droughts in the PPR (NOAA 18921996). Moreover, the strong summer breeding response in both years occurred while ponds were filling during late spring and summer, creating conditions conducive to production of aquatic invertebrates (Euliss et al. 1999). At Jamestown, North Dakota, near the center of the FBSA, annual precipitation during 1988 to 1992 was as low as $28.6 \mathrm{~cm}$ (1988), and few shallow wetland basins in eastern North Dakota held water in several springs (Krapu et al. 1997). In 1993, when the drought cycle ended, annual precipitation increased to $76.7 \mathrm{~cm}$, with July being the second wettest on record. Precipitation in July 1993, $28.1 \mathrm{~cm}$, was only slightly below the total annual precipitation in 1988 and was $20.1 \mathrm{~cm}$ above average. Annual precipitation in 1994 and 1995 was 59.4 and $55.0 \mathrm{~cm}$, respectively. Wetland habitat remained plentiful in 1994 and 1995, but no comparable rainfall events or flooding occurred on the study area in summer; apparently, fewer Mallards, Bluewinged Teal, and Gadwalls nested in mid- and late summer based on the number of broods present during fall (Table 3). Further research is needed to better understand how duck species vary in the way environmental information is transduced into endocrine secretions that regulate length of the breeding cycle (see Bluhm 1992).

Adaptations that allow Blue-winged Teal, Mallards, and Gadwalls to nest later in spring than shovelers and pintails results in a tradeoff because of the higher probability that teal, Mallards, and Gadwalls will breed into summer, 
potentially leading to high mortality of breeding females and young. Because breeding sufficiently late to cause major losses of young (as in 1993) appears to occur infrequently, the benefits of being able to breed later in years when water is abundant probably outweigh the risks. Among Mallards, the magnitude of renesting effort in spring can determine whether populations are maintained in environments subjected to high rates of nest loss (Cowardin et al. 1985). This relationship reflects the importance to population status of how reproductive mechanisms respond to wetland habitat conditions in spring.

The large size of Mallard, Blue-winged Teal, and Gadwall broods from 20 to 30 September 1993 suggests that males maintain high rates of spermatogenesis for up to two months beyond the summer solstice, which is longer than previously thought. Duration of sperm storage by female Mallards averaged 9.4 days (Elder and Weller 1954), suggesting that the apparent high fertility in summer-initiated clutches on my study area resulted because males remained reproductively active (vs. sperm having been stored by females for protracted periods). Spermatozoa are lost at a more rapid rate from reproductive tracts of female Mallards than among non-waterfowl species that have been studied (Cunningham 1997), which also supports the conclusion that males successfully breed throughout summer in North Dakota. Little is known about how synchrony in reproductive cycles of male and female dabbling ducks is maintained through summer. However, female Song Sparrows (Melospiza melodia) treated with estradiol to keep them in a reproductive state long after the normal breeding season induced their unmanipulated mates to remain reproductively active (Runfeldt and Wingfield 1985). Similarly, male dabbling ducks may be stimulated to remain reproductively active when breeding females are present.

Interspecific differences in timing of termination of breeding in temperate-nesting dabbling ducks, including the capacity of some species to breed through summer when habitat conditions are exceptionally favorable, suggest that refractory mechanisms are more varied and complex than suggested by earlier studies. Interspecific variation in length of breeding affects many aspects of a species' biology and thus offers numerous potential avenues for further study. A major gap in information is a lack of understanding of proximate causes of interspecific variation in timing of termination of breeding among temperate-breeding dabbling ducks. Wide variation among dabbling ducks in responsiveness to non-photic cues late in the breeding season suggests that greater attention should be focused on the scale and pathways of involvement of non-photic influences in controlling length of breeding. To date, research on refractory mechanisms in dabbling ducks has focused mostly on Mallards, but future work would benefit from a greater emphasis on comparative studies.

\section{ACKNOWLEDGMENTS}

This study benefited from the assistance of numerous individuals and the support of administrators at Northern Prairie Wildlife Research Center. I thank Ron Reynolds, Habitat and Populations Evaluation Team of the U.S. Fish and Wildlife Service, Bismarck, North Dakota, for allowing me to use a subset of his duck nest records collected during nest surveys from 1993 to 1995 . I am grateful to the following colleagues who participated in the fall brood surveys: Bruce Barbour, Bonnie Bowen, Deborah Buhl, Tom Buhl, Dave Brandt, Lewis Cowardin, Bobby Cox, Harold Duebbert, Chris Dwyer, Betty Euliss, Ray Greenwood, Harold Kantrud, Tom Klett, Diane Larson, John Lokemoen, Wesley Newton, Pamela Pietz, Alan Sargeant, Terry Shaffer, Marsha Sovada, Larry Strong, and Robert Woodward. I appreciate the help provided by Paul Padding of the Migratory Bird Management Office of the U.S. Fish and Wildlife Service for coordinating collection of data on fall shot flightless juvenile dabbling ducks submitted by a random sample of hunters for the fall duck harvest survey during 1993 to 1995. I thank Terry Shaffer and Wesley Newton for assistance in designing fall brood surveys, Dave Brandt for helping set up surveys and process information, Dave Brandt and Glen Sargeant for preparing figures, and Jane Austin and Pamela Pietz for bringing to my attention pertinent literature. I am grateful to Glen Sargeant and Julie Beiser for support in statistical analyses and Cynthia Bluhm, Bobby Cox, Tom Hahn, Frank McKinney, Glen Sargeant, John Wingfield, and two anonymous reviewers for making valuable comments on earlier drafts of this manuscript. Last, I want to thank my parents for allowing me to spend much time afield observing birds in my youth, which led to observations that prompted the current study.

\section{Literature Cited}

Bataille, K. J., And G. A. Baldassarre. 1993. Distribution and abundance of aquatic macro-in- 
vertebrates in three prairie pothole wetlands. Wetlands 13:260-269.

Bellrose, F. C. 1979. Species distributions, habitats, and characteristics of breeding dabbling ducks in North America. Pages 1-15 in Waterfowl and wetlands-An integrated review (T. A. Bookhout, Ed.). North Central Section of The Wildlife Society, Madison, Wisconsin.

Bellrose, F. C. 1980. Ducks, geese, and swans of North America. Stackpole Books, Harrisburg, Pennsylvania.

BluHM, C. K. 1992. Environmental and endocrine control of waterfowl reproduction. Pages 323364 in Ecology and management of breeding waterfowl (B. D. J. Batt, A. D. Afton, M. G. Anderson, C. D. Ankney, D. H. Johnson, J. A. Kadlec, and G. L. Krapu, Eds.). University of Minnesota Press, Minneapolis.

COWARDIN, L. M., D. S. GILMER, AND C. W. SHAIFFER. 1985. Mallard recruitment in the agricultural environment of North Dakota. Wildlife Monographs No. 92.

Cox, R. R., Jr., M. A. Hanson, C. C. Roy, N. H. EULISS, Jr., D. H. JOHNSON, AND M. G. ButLeR. 1998. Mallard duckling growth and survival in relation to aquatic invertebrates. Journal of Wildlife Management 62:124-133.

Cunningham, E. J. A. 1997. Forced copulation and sperm competition in the Mallard Anas platyrhynchos. Ph.D. thesis, University of Sheffield, Sheffield, United Kingdom.

DERRICKSON, S. R. 1978. The mobility of breeding Pintails. Auk 95:104-114.

DONHAM, R. S. 1979. Annual cycle of plasma luteinizing hormone and sex hormones in male and female Mallards (Anas platyrhynchos). Biology of Reproduction 21:1273-1285.

DREWIEN, R. C., AND P. F. SPRINGER. 1969. Ecological relationships of breeding Blue-winged Teal to prairie potholes. Pages 102-115 in Saskatoon wetlands seminar. Canadian Wildlife Service Report Series No. 6.

DuBowY, P. J. 1988. Waterfowl communities and seasonal environments: Temporal variability in interspecific competition. Ecology 69:1439-1453.

Dzubin, A., AND J. B. Gollop. 1972. Aspects of Mallard breeding ecology in Canadian parkland and grassland. Pages 113-152 in Population ecology of migratory birds (R. I. Smith, J. R. Palmer, and T. S. Baskett, Eds.). United States Fish and Wildlife Service Research Report No. 2.

ELDER, W. H., AND M. W. WELLER. 1954. Duration of fertility in the domestic Mallard hen after isolation from the drake. Journal of Wildlife Management 18:495-502.

ELDRIDGE, J. L., AND G. L. KRAPU. 1988. The influence of diet quality on clutch size and laying pattern in Mallards. Auk 105:102-110.

ESLER, D., AND J. B. GRAND. 1994. The role of nutrient reserves for clutch formation by Northern Pintails in Alaska. Condor 96:422-432.

Euliss, N. H., JR., D. A. WrublesKI, AND D. M. MuSHET. 1999. Wetlands of the prairie pothole region: Invertebrate species composition, ecology, and management. Pages 471-514 in Invertebrates in freshwater wetlands of North America: Ecology and management (D. P. Batzer, R. B. Rader, and S. A. Wissinger, Eds.). John Wiley and Sons, New York.

FARNER, D. S., R. S. DONHAM, K. S. MATT, P. W. MATTOCKS, JR., M. C. MOORE, AND J. C. WingFIELD. 1983. The nature of photorefractoriness. Pages 149-166 in Avian endocrinology: Environmental and ecological perspectives (S. Mikami, K. Homma, and M. Wada, Eds.). Spring-Verlag, Berlin.

Gollop, J. B., AND W. H. MARshall. 1954. A guide for aging duck broods in the field. Report of the Mississippi Flyway Council Technical Section.

Greenwood, R. G., A. B. SARgeant, D. H. Johnson, L. M. CoWARdiN, AND T. L. SHAFFer. 1995. Factors associated with duck nest success in the prairie pothole region of Canada. Wildlife Monographs No. 128.

HAASE, E. 1983. The annual reproductive cycle in Mallards. Journal of Steroid Biochemistry 19: 731-737.

HAASE, E., P. J. ShARP, AND E. PAUlKe. 1985. Seasonal changes in the concentrations of plasma gonadotropins and prolactin in wild Mallard drakes. Journal of Experimental Zoology 234:301-305.

Hahn, T. P., T. Boswell, J. C. Wingfield, AND G. F. BALL. 1997. Temporal flexibility in avian reproduction. Current Ornithology 14:39-80.

HALL, D. J. 1964. An experimental approach to the dynamics of a natural population of Daphnia galeata mendotae. Ecology 45:94-112.

HoHN, E. O. 1947. Sexual behaviour and seasonal changes in the gonads and adrenals of the Mallard. Proceedings of the Zoological Society of London 117:281-304.

JoHnsON, D. H. 1979. Estimating nest success: The Mayfield method and an alternative. Auk 96: 651-661.

JOHNSON, D. H., AND J. W. GRIER. 1988. Determinants of breeding distributions of ducks. Wildlife Monographs No. 100.

JoHnsON, O. W. 1961. Reproductive cycle of the Mallard duck. Condor 63:351-364.

JoHNSON, O. W. 1966. Quantitative features of spermatogenesis in the Mallard (Anas platyrhynchos). Auk 83:233-239.

Klett, A. T., H. F. Duebbert, C. A. FaAnes, and K. F. Higgins. 1986. Techniques for studying nest success of ducks in upland habitats in the prairie pothole region. United States Fish and Wildlife Service Resource Publication No. 158.

KRAPU, G. L. 1974. Feeding ecology of Pintail hens during reproduction. Auk 91:278-290. 
KRAPU, G. L. 1981. The role of nutrient reserves in Mallard reproduction. Auk 98:29-38.

Krapu, G. L., R. J. Greenwood, C. P. Dwyer, K. M. KRAFT, AND L. M. CoWARDIN. 1997. Wetland use, settling patterns and recruitment in Mallards. Journal of Wildlife Management 61:736746.

Krapu, G. L., A. T. Klett, AND D. G. Jorde. 1983. The effect of variable water conditions on Mallard reproduction. Auk 100:689-698.

Krapu, G. L., P. J. Pietz, D. A. Brandt, And R. R. Cox, Jr. 2000. Factors limiting Mallard brood survival in prairie pothole landscapes. Journal of Wildlife Management 64:553-561.

KRAPU, G. L., AND K. J. ReInecke. 1992. Foraging ecology and nutrition. Pages 1-29 in Ecology and management of breeding waterfowl (B. D. J. Batt, A. D. Afton, M. G. Anderson, C. D. Ankney, D. H. Johnson, J. A. Kadlec, and G. L. Krapu, Eds.). University of Minnesota Press, Minneapolis.

LofTS, B., AND C. J. F. CoOmBs. 1965. Photoperiodism and testicular refractory period in the Mallard. Journal of Zoology (London) 146:44-54.

Lokemoen, J. T., H. F. Duebbert, AND D. E. Sharp. 1990. Homing and reproductive habits of Mallards, Gadwalls, and Blue-winged Teal. Wildlife Monographs No. 106.

Mathsoft. 1997. S-Plus 4. Mathsoft, Seattle, Washington.

Murton, R. K., AND J. KeAR. 1976. The role of daylength in regulating the breeding seasons and distribution of wildfowl. Pages 337-360 in Light as an ecological factor, vol. 2 (R. Bainbridge, Ed.). Blackwell Scientific Publishers, Oxford.

NAtional Oceanic AND Atmospheric AdminisTRATION. 1892-1996. Climatological data: North Dakota, monthly summaries. National Climatic Center, Asheville, North Carolina.

NudDS, T. D., AND J. N. BowLby. 1984. Predator-prey size relationships in North American dabbling ducks. Canadian Journal of Zoology 62:20022008.

Pospahala, R. S., D. R. Anderson, And C. J. Henny. 1974. Population ecology of the Mallard. II.
Breeding habitat conditions, size of breeding populations, and production indices. U.S. Fish and Wildlife Service Resource Publication No. 115.

Poston, H. J. 1969. Relationships between the Shoveler and its breeding habitat at Strathmore, Alberta. Pages 132-137 in Saskatoon wetlands seminar. Canadian Wildlife Report Series No. 6.

Reynolds, R. E., T. L. Shaffer, J. R. SAuer, AND B. G. Peterson. 1994. Conservation Reserve Program: Benefit for grassland birds in the Northern Plains. Transactions North American Wildlife and Natural Resources Conference 59:328336.

Runfeldt, S., AND J. C. WingField. 1985. Experimentally prolonged sexual activity in female sparrows delays termination of reproductive activity in their untreated mates. Animal Behaviour 33:403-410.

SerIE, J. R., AND G. A. SWANSON. 1976. Feeding ecology of breeding Gadwalls on saline wetlands. Journal of Wildlife Management 40:69-81.

SMITH, A. G. 1971. Ecological factors affecting waterfowl production in the Alberta parklands. United States Fish and Wildlife Service Resource Publication No. 98.

SMITH, R. I. 1970. Response of Pintail breeding populations to drought. Journal of Wildlife Management 34:943-946.

Swanson, G. A., G. L. Krapu, AND J. R. Serie. 1979. Foods of laying female dabbling ducks on the breeding grounds. Pages 47-57 in Waterfowl and wetlands: An integrated review (T. A. Bookhout, Ed.). North Central Section of The Wildlife Society, Madison, Wisconsin.

United States Army Corps of Engineers. 1994. The great flood of 1993: Post-flood report, Upper Mississippi River Basin. United States Army Corps of Engineers, St. Paul, Minnesota.

United States Fish and Wildlife Service. 1998. Waterfowl population status, 1998. United States Department of the Interior, Washington, D.C.

WELLER, M. W. 1956. A simple field candler for waterfowl eggs. Journal of Wildlife Management 20:111-113.

Associate Editor: J. C. Wingfield 